\title{
熱ストレス負荷とアスタキサンチン投与の組み合わせが 廃用性筋萎縮に与える影響
}

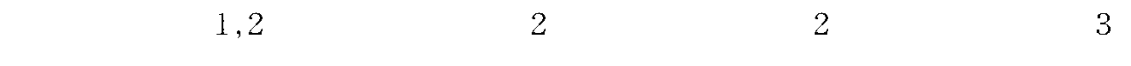 \\ 後藤 勝 正 $^{4}$ 磯 山 智 美 $^{5)}$ 内 藤久 $\pm^{1)}$ 大森大二郎 ${ }^{6)}$ 吉 岡 利 忠 ${ }^{7)}$
EFFECTS OF COMBINATION OF HEAT STRESS AND ASTAXANTHIN SUPPLEMENTATION ON DISUSE MUSCLE ATROPHY

\author{
Toshinori Yoshihara, Takao Sugiura, Tsubasa Sibaguchi, Yuki Yamamoto, \\ Katsumasa Goto, TOMOMI IsOYama, Hisashi naito, DajJiro OHMori and TOSHITAda Yoshioka
}

\begin{abstract}
The purpose of this study was to examine the effects of combination of a heat stress and astaxanthin supplementation, known as a potent anti-oxidative nutrient, on muscle protein degradation and disuse muscle atrophy. Fifty-two male Wistar rats $(261.7 \pm 1.17 \mathrm{~g})$ were divided into five groups: control (Cont, $n=10$ ), suspension (Sus, $n=11$ ), heat stress and suspension (Heat, $n=10$ ), astaxanthin and suspension $(A x, n=10)$, and heat stress, astaxanthin and suspension $(H+A, n=11)$. There were no significant differences in $\mathrm{Cu}, \mathrm{Zn}-\mathrm{SOD}$, cathepsin $\mathrm{L}$ and caspase-3 levels among the Heat, $\mathrm{Ax}$ and $\mathrm{H}$ + A groups in the soleus and plantaris muscles. Although levels of calpain 2 and ubiquitinated protein in the myofibrillar fraction in the soleus muscle were not significantly different among the Heat, Ax and $\mathrm{H}+\mathrm{A}$ groups, levels in the $\mathrm{H}+\mathrm{A}$ group were significantly $(\mathrm{p}<0.05)$ lower than Sus. Concerning atrophied plantaris muscles, the $\mathrm{H}+\mathrm{A}$ group significantly $(\mathrm{p}<0.05)$ suppressed the expression of calpain 1 in the myofibrillar fraction, but there were no marked changes of proteolytic indexes. These data indicate that the combination of the heat stress and astaxanthin supplementation could be effective in inhibiting muscle protein degradation in disuse atrophy of the soleus.
\end{abstract}

(Jpn. J. Phys. Fitness Sports Med. 2010, $59: 303 \sim 312$ )

key words : hindlimb-suspension, protein degradation, heat stress, anti-oxidative nutrient

\footnotetext{
I . 緒言

不活動により誘発される筋萎縮（廃用性筋萎縮) は, 骨格筋活動の低下による活性酸素種 (Reactive Oxygen Species：ROS) 産生の増大と光れに関連し たタンパク質分解の亢進によって生じることが報告

1)順天堂大学大学院スポーツ健康科学研究科 干270-1695 千葉県印西市平賀学園台 1-1

2) 山口大学教育学部スポーツ健康科学教室 干753-8513 山口市大字吉田1677-1

3) 筑波大学大学院人間総合科学研究科 干 305-8574 茨城県つくば市天王台 1-1-1

4)豊橋創造大学リハビリテーション学部 干440-8511 愛知県豊橋市牛川町松下 20-1

$5)$ 東洋酵素化学株式会社 干279-0041 千葉県浦安市堀江4-4-27

6)順天堂大学医学部化学研究室 干270-1695 千葉県印西市平賀学園台1-1

7)弘前学院大学 干036-8577 青森県弘前市稔町 13-1
}

されている ${ }^{1,2)}$. 生体内において, ROSの産生が抗 酸化能力を上回ることにより酸化ストレスが増大 し, 主要な筋タンパク質分解経路として知られてい るリソソーム系, カルパイン系, ユビキチンープロ テアソーム系を活性化し, 筋タンパク質の分解が方 進することが知られている ${ }^{2,3)}$.また, 酸化ストレ
Graduate School of Health and Sports Science, Juntendo University, Inzai, Chiba 270-1695, Japan

Department of Exercise and Health Sciences, Faculty of Education, Yamaguchi University, Yamaguchi, Yamaguchi 753-8513, Japan

Graduate School of Comprehensive Human Sciences, University of Tsukuba, Tsukuba, Ibaraki 305-8574, Japan

Laboratory of Physiology, Toyohashi SOZO University, Toyohashi, Aichi 440-8511, Japan

Toyo Koso Kagaku Co. Ltd., Urayasu, Chiba, 279-0041, Japan

Department of Chemistry, School of Medicine, Juntendo University, Japan

Hirosaki Gakuin University, Hirosaki, Aomori 036-8577, Japan 
スの増大は, ミトコンドリアからのチトクロムcの 放出を促進し, Caspase-3を介した筋核アポトーシ スを誘導することで筋萎縮を引き起こすと考えられ ている ${ }^{2)}$.

このような廃用性筋萎縮に対する対抗策として， 熱ショックタンパク質 (Heat Shock Protein：HSP) や抗酸化剂であるアスタキサンチンに着目した研究 が行われている．HSPは体温上昇だけでなく, 酸化 ストレスや虚血などの樣々なストレスによって誘導 されるストレスタンパク質で，ストレス環境から細 胞を保護するために，損傷したタンパク質の凝集抑 制，または一部変性したタンパク質の修復などの機 能を有している．これまで, Naitoらは, 尾部懸垂に よって筋萎縮を誘導する前の熱ストレス負荷が， HSP72発現量を増加させ , ヒラメ筋の萎縮を抑制し たことを報告している ${ }^{4)}$.一方, 廃用性筋萎縮に対 する抗酸化刘の効果については, ビタミンEを中心 に多くの研究が行われているが ${ }^{5 \sim 7)}$, 近年アスタキ サンチンが $\beta$-カロテンやビタミンE以上の抗酸化能 力を持つことが明らかになり，筋萎縮に対するアス タキサンチンの効果に関する報告も散見されるよう

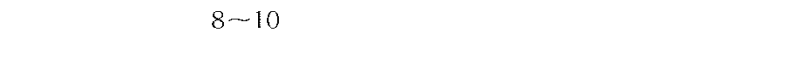
まれるカロテノイドの一種で, 弚の抗酸化能力はビ タミンE ( $\alpha$-トコフェロール) と比較し, 一重項酸 素に対しては約100倍, 過酸化脂質生成反応に対し ては約1000倍高いといわれている ${ }^{11)}$.これまで,我々 は10日間のギプス固定に誘発される筋萎縮に対し， アスタキサンチンを投与することて酸化ストレスや タンパク質分解酵素の発現が低下し, 足底筋におけ る萎縮が抑制されたことを報告した8)．

以上のように，廃用性筋萎縮に対する対抗策とし て熱ストレス負荷やアスタキサンチン投与に着目し た研究が行われているが, 兴れらの組み合わせの処 置が筋萎縮に与える影響を検討した報告はこれまで 行われていない, 乥こで本研究は, 筋萎縮誘導前後 における熱ストレス負荷とアスタキサンチン投与の 組み合わせの処置が筋萎縮抑制に効果的であるか否 かを, 筋タンパク質分解に関わるタンパク質分解経路 の指標から検討することを目的とした .

$$
\text { II. 方法 }
$$

\section{A. 実験動物}

本研究は, 国立大学法人山口大学における動物使
用に関する規則に従い実施した . 実験動物には 8 週 齢のWistar系雄ラット52匹（体重；261.7 $\pm 1.17 \mathrm{~g}$ ) を用い，室温 $24.0 \pm 1.0^{\circ} \mathrm{C}$, 湿度 $50 \sim 60 \%, 12$ 時間の 明暗サイクルを維持した環境下で飼育を行った . 1 週間の予備飼育後, ラットを体重が等しくなるよう に対照群 (Cont群；n=10), 尾部懸垂群 (Sus群; $\mathrm{n}=11$ ), 尾部懸垂十熱ストレス群（Heat群；n=10), 尾部懸垂+アスタキサンチン摂取群 $(\mathrm{Ax}$ 群 $; \mathrm{n}=10)$, および尾部懸垂十熱ストレス+アスタキサンチン攝 取群 $(\mathrm{H}+\mathrm{A}$ 群；n=11) に分け，Cont群，Sus群およ びHeat群には粉末飼料 (CE-2, Clea Japan, INC.) にアスタキサンチン非含有パウダー (東洋酵素化学 株式会社）を混ぜた飼料を，Ax群およびH+A群には アスタキサンチン含有パウダー (東洋酵素化学株式 会社）を混ぜた飼料を飼育終了時まで捸取させた . 実験試料の配合については先行研究を参考にして ${ }^{10)}$, アスタキサンチン $(0.04 \%)$ 以外の組成がほぼ等し くなるように調整した . 投与開始 2 週間後, Cont群 を除く全ての群には 7 日間の尾部懸垂を行った . ま た,Heat群および H+A群には尾部懸垂開始 1 日前， 1 日後， 3 日後および 5 日後の定時に 1 時間尾部懸 垂を解除し， $42^{\circ} \mathrm{C}$ に設定されたチャンバー内にラッ 卜を入れて30分間の熱ストレスを負荷した .なお， 熱ストレス負荷を除いた残りの30分間は，ラットの 移動時間および熱ストレス後の回復時間とした．熱 ストレス負荷後, サーミスタ (日本光電, $2762 \mathrm{C}$ )

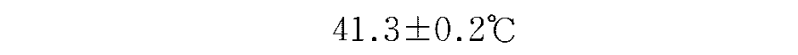
Sus群およびAx群も同樣に尾部懸垂を解除した . 飼 育期間中，ラットの捸食量および体重を測定し，飼 料や水は自由に摂取させた。

飼育期間終了後, ラットをエーテル麻酔下で屠殺 し，ヒラメ筋および足底筋を摘出した . 摘出した筋 は速やかに筋重量を測定し, 分析までー $80^{\circ} \mathrm{C} て ゙$ 凍結 保存した。

\section{B. サンプル処理}

凍結保存した筋の筋腹から，50〜 $100 \mathrm{mg}$ 筋切片 を切り出し, 10倍量のIsolation Buffer [20 m M Tris- $\mathrm{HCl} \mathrm{pH} 7.4,25 \mathrm{mM} \mathrm{KCl}, 5 \mathrm{mM}$ EDTA , $5 \mathrm{mM}$ EGTA , $1 \mathrm{mM}$ Dithiothreitol(DTT) , 1\%(v/v)Phoshatase inhibitor cocktail (nacalai tesque, 07574-61), $1 \%(\mathrm{v} / \mathrm{v})$ Protease inhibitor cocktail(nacalai tesque, 25955-11) ] を加えてホモジナイズし遠心分離した 
$\left(3000 \mathrm{rpm}, 4^{\circ} \mathrm{C}, 10\right.$ 分) . 分離後, 上清を可溶性タン パク質サンプルとして回収し，残った沈殿を用い Solaro らの方法 ${ }^{12)}$ により筋原線維タンパク質を抽出 した . 得られた可溶性タンパク質濃度は, Protein Assay Kit（Bio Rad）を用いて測定し, 濃度が1 $\mathrm{mg} / \mathrm{ml}$ になるようにSodium-Dodecylsulfate (SDS) Sample Buffer [62.5 mM Tris- $\mathrm{HCl}$ (pH 6.8), 2.3\% $(\mathrm{w} / \mathrm{v})$ SDS , 30\% (v/v) Glycerol , $0.05 \%(\mathrm{w} / \mathrm{v})$ Bromophenol-blue , 5\% (v/v) 2-Mercaptoethanol] を用いて調整した。また，筋原線維タンパク質濃度 はビュレット法を用いて測定し，濃度が $2 \mathrm{mg} / \mathrm{ml}$ にな るようにSDS Sample Bufferを用いて調整した。钅の 後, 全てのサンプルを $60^{\circ} \mathrm{C} て ゙ 10$ 分間加熱し, 分析ま

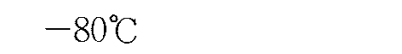

\section{C. イムノブロッティング}

タンパク質の分析には, SDS Polyacrylamide Gel Electrophoresis (SDS-PAGE) 法を用いた.サンプ ルは, 各レーンあたり $20 \mu \mathrm{g}$ を負荷し，10 $\mu$ の分子 量マーカー (Precision Plus Protein Standards, Bio Rad，161-0374）と共に泳動した . 泳動後，ミニト ランスブロットセル (Bio Rad) を用いて, $8^{\circ} \mathrm{C}$ に設 定したインキュベーター内において $100 \mathrm{~V} て ゙ 1$ 時間 通電し, Polyvinylidene difluoride membrane (PVDF膜：GE Healthcare, RPN303F) にタンパク 質を転写した . 兴の後, $5 \%(\mathrm{w} / \mathrm{v})$ Skim milk/TTBS $[40 \mathrm{mM}$ Tris- $\mathrm{HCl}(\mathrm{pH} 7.5), 300 \mathrm{mM} \mathrm{NaCl}, 0.1 \%$ (v/v) Tween 20] を用いて 1 時間のブロッキング処 理を行った .

ブロッキング処理後， $8^{\circ} \mathrm{C}$ に設定されたインキュ ベーター内においてCan Get Signal 1 (TOYOBO , NKB1-101) で5 $\times 10^{2} \sim 1 \times 10^{3}$ 倍に希釈した一次抗体 と一晚反応させた . 用いた抗体は, Anti-Cathepsin L (Bio Vision ,3741-100) ,Anti-Calpain 1(Cellsignaling , 2556), Anti-Calpain 2 (Cellsignaling, 2539), Anti-Multi Ubiquitin (Stressgen, SPA-205)，および Anti-Caspase-3 (Stressgen, AAP-113) であった . ただし, Anti-Cu,Zn-SOD (Stressgen, SOD-100) は TTBSで $1 \times 10^{4}$ 倍希釈とした .

一次抗体反応終了後, TTBSで10分 $\times 3$ 回洗浄し, 室温で 2 時間の二次抗体反応を行った .二次抗体は， ユビキチン化タンパク質の場合はCan Get Signal 2 (TOYOBO，NKB1-101) で2 $\times 10^{4}$ 倍に希釈した
Anti-Mouse IgG Peroxidase Conjugate (SIGMA , A-4416)，Cu,Zn-SODの場合はTTBSで $2 \times 10^{4}$ 倍に希 釈したAnti-Rabbit IgG Peroxidase Conjugate (SIGMA，A-6154) を用い, 光れ以外はCan Get Signal $2 て ゙ 2 \times 10^{4}$ 倍に希釈したAnti-Rabbit IgG Peroxidase Conjugateを用いた二次抗体反応終了後， TTBSで10分 $\times 3$ 回洗浄し, ECL Plus (GE Heal. thcare, RPN2132)，およびECL (GE Healthcare， RPN2106）を用いて発光させた .

\section{D. 分析}

発光させたPVDF膜は冷却CCDカメラ (Light Capture , ATTO , AE-6955) でコンピューターに取り 込み，画像解析ソフト (CS Analyzer, ATTOおよび Scion Image，Scion Corporation) を用いて分析を行っ た、各タンパク質の発現量は, ヒラメ筋および足底 筋の光れ光れについて，Cont群を $100 \%$ とし比較検討 した。

\section{E. 統計}

得られたデータは, 全て平均值士標準誤差で示し た. 統計学的分析は一元配置の分散分析を行い, 有 意差か認められた場合には，Turkey-Kramer法によ る多重比較を行った，有意水準は，全て危険率 $5 \%$ 末満とした。

$$
\text { III. 結果 }
$$

\section{A. 体重·摄食量}

熱ストレス負荷とアスタキサンチン投与，および ぞれらの組み合わせが尾部懸垂後の体重および摂食 量に及ぼす影響を表 1 に示した . 尾部懸垂後の体重 は, Cont群と比較してHeat群, Ax群, およびH+A 群において有意に低い值を示した $(\mathrm{p}<0.05)$.一方， 捸食量は尾部懸垂前後の各群間において有意な差は 認められなかった .

\section{B. 筋重量·相対筋重量}

表 2 に熱ストレス負荷とアスタキサンチン投与， およびそれらの組み合わせが尾部懸垂後のヒラメ筋 と足底筋の筋重量および体重 $1 \mathrm{~kg}$ 当りの相対筋重量 に及ぼす影響を示した .ヒラメ筋と足底筋の両筋に おいて, Cont群と比較して尾部懸垂群の筋重量は有 意に低い值を示した $(\mathrm{p}<0.05)$. 一方，ヒラメ筋の 
Table 1. Body weights and food consumption.

\begin{tabular}{ccccccc}
\hline & & Cont $(n=10)$ & Sus $(n=11)$ & Heat $(n=10)$ & $A x(n=10)$ & $H+A(n=11)$ \\
\hline \multirow{2}{*}{ Body weight (g) } & pre & $401 \pm 8$ & $391 \pm 7$ & $390 \pm 14$ & $403 \pm 16$ & $389 \pm 12$ \\
& post & $409 \pm 7$ & $376 \pm 7$ & $356 \pm 8 *$ & $368 \pm 11 *$ & $365 \pm 11 *$ \\
\hline Food consumption & pre & $23.2 \pm 0.3$ & $23.4 \pm 0.3$ & $23.3 \pm 0.3$ & $23.9 \pm 0.7$ & $24.1 \pm 0.6$ \\
(g/day) & post & $21.9 \pm 0.7$ & $20.1 \pm 0.9$ & $19.2 \pm 1.3$ & $19.2 \pm 0.9$ & $20.1 \pm 1.1$ \\
\hline
\end{tabular}

Values are means \pm SE. Cont: Control; Sus: Suspension; Heat: Heat stress and suspension; Ax: Astaxanthin and suspension; $\mathrm{H}+\mathrm{A}$ : Heat stress, Astaxanthin and suspension. * Significantly different $(\mathrm{p}<0.05)$ from Cont (post).

Table 2. Muscle weights and relative muscle weights.

\begin{tabular}{ccccccc}
\hline & & Cont $(n=10)$ & Sus $(n=11)$ & Heat $(n=10)$ & $A x(n=10)$ & $H+A(n=11)$ \\
\hline \multirow{2}{*}{ Muscle weight (mg) } & SOL & $168.2 \pm 6.7$ & $122.0 \pm 3.5 *$ & $131.1 \pm 2.4 *$ & $128.9 \pm 4.7 *$ & $129.9 \pm 4.5 *$ \\
& PLA & $435.0 \pm 11.1$ & $369.3 \pm 6.6 *$ & $367.7 \pm 10.2 *$ & $378.4 \pm 13.8 *$ & $360.1 \pm 10.1 *$ \\
\hline Relative muscle & SOL & $410.7 \pm 12.8$ & $325.3 \pm 9.5 *$ & $368.7 \pm 7.4$ & $351.9 \pm 13.6 *$ & $357.5 \pm 11.2 *$ \\
weight (mg/kg BW) & PLA & $1063.7 \pm 20.3$ & $984.3 \pm 17.2 *$ & $1032.6 \pm 22.0$ & $1028.6 \pm 19.9$ & $989.2 \pm 16.0$ \\
\hline
\end{tabular}

Values are means \pm SE. SOL: Soleus muscle; PLA: plantaris muscle. * Significantly different $(p<0.05)$ from Cont.

相対筋重量は, Cont群と比較してSus群，Ax群，お よびH+A群で有意に低い值を示した $(\mathrm{p}<0.05)$. また, 足底筋の相対筋重量は, Cont群と比較して Sus群において有意に低い値を示した $(p<0.05)$.

\section{C. $\mathrm{Cu}, \mathrm{Zn}-\mathrm{SOD}$}

图 1 に熱ストレス負荷とアスタキサンチン投与 , お よびそれらの組み合わせがヒラメ筋と足底筋の $\mathrm{Cu}, \mathrm{Zn}-\mathrm{SOD}$ 発現量に及ぼす影響を示した. $\mathrm{Cu}, \mathrm{Zn}-\mathrm{SOD}$ 発現量は, 両筋のいずれの群間においても有意差は認 められなかった .

D. Cathepsin L

図 2 に熱ストレス負荷とアスタキサンチン投与， および光れらの組み合わせがヒラメ筋と足底筋の Cathepsin Lの発現量に及ぼす影響を示した。 Cathepsin L発現量は, 両筋のいずれの群間において も有意差は認められなかった .

\section{E. Calpain $1 \cdot$ Calpain 2}

図 3 に熱ストレス負荷とアスタキサンチン投与， および关れらの組み合わせがヒラメ筋と足底筋の可 溶性分画 $(\mathrm{A} \cdot \mathrm{B})$ および筋原線維分画 $(\mathrm{C} \cdot \mathrm{D})$ に おけるCalpain $1 \cdot 2$ 発現量に及ぼす影響を示した . 可溶性分画におけるCalpain $1 \cdot 2$ 発現量は, 両筋の
いずれの群間においても有意差は認められなかっ た，一方，足底筋の筋原線維分画におけるCalpain 1 発現量は, Cont群と比較して $\mathrm{H}+\mathrm{A}$ 群で有意に低い值 を示したが $(p<0.05)$ ，ヒラメ筋では各群間に有意 差は認められなかった . また，ヒラメ筋の筋原線維 分画におけるCalpain 2発現量は, Sus群と比較して Heat群およびH+A群で有意に低い值を示したが（p $<0.05)$, 足底筋では各群間に有意差は認められな かった .

\section{F．ユユビキチン化タンパク質}

図 4 に熱ストレス負荷とアスタキサンチン投与， および关れらの組み合わせがヒラメ筋と足底筋の可 溶性分画 (A) および筇原線維分画 (B) における工 ビキチン化タンパク質発現量に及ぼす影響を示し た．可溶性分画におけるユビキチン化タンパク質発 現量は，両筋のいずれの群間においても有意差は認 められなかったが，ヒラメ筋の筋原線維分画では， Sus群と比較してH+A群で有意に低い值を示した（p $<0.05)$ ．一方，足底筋では，各群間に有意差は認 められなかった .

\section{G. Caspase-3}

図 5 に熱ストレス負荷とアスタキサンチン投与， およびそれらの組み合わせがヒラメ筋と足底筋の 


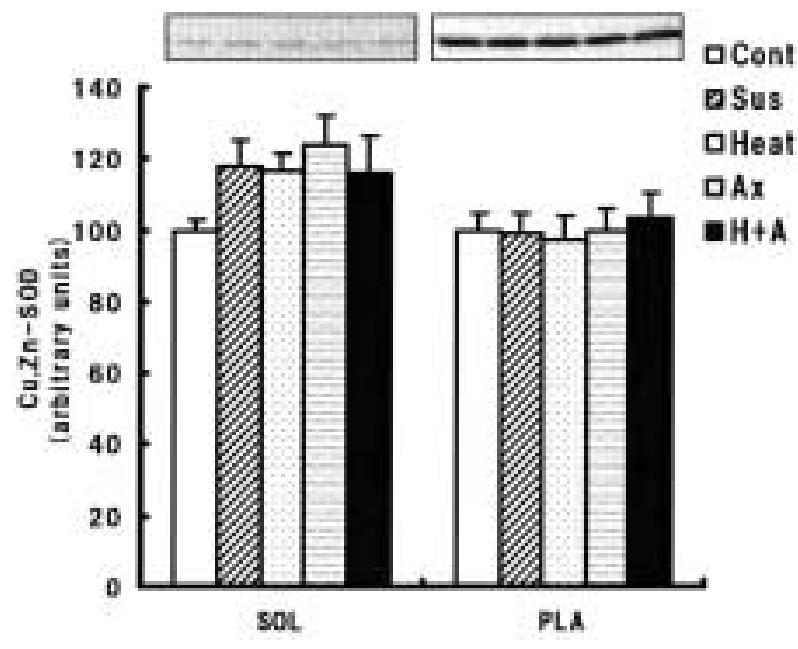

Fig.1. The expression of $\mathrm{Cu}, \mathrm{Zn}-\mathrm{SOD}$ from the soleus and plantaris muscles. Values are means \pm SE. All date are represented as the percent of control values.

(A)

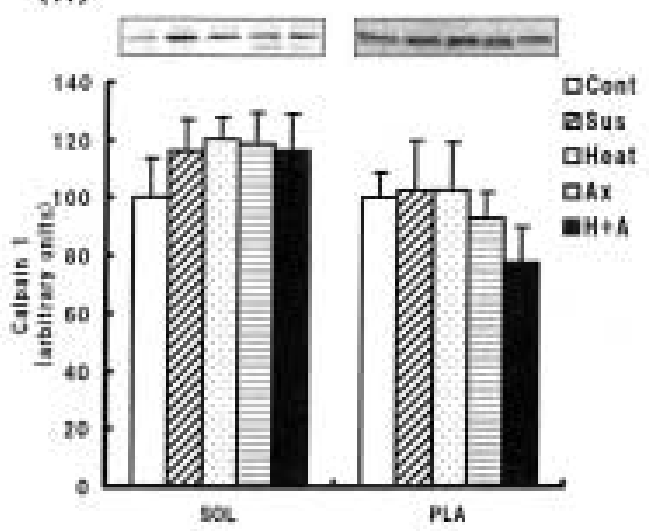

(c)

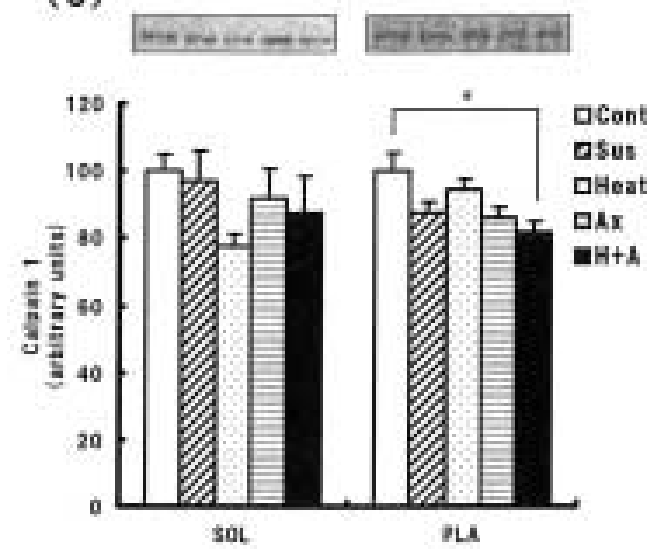

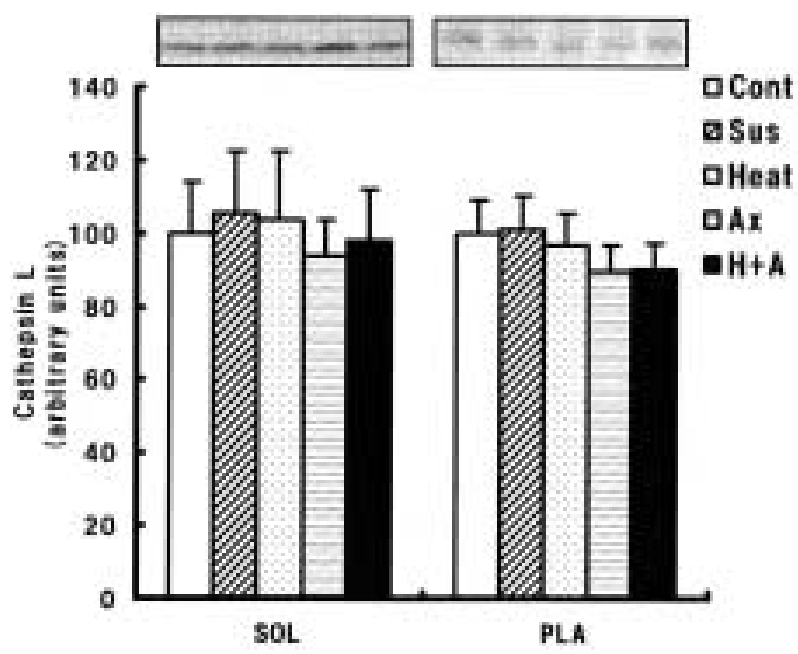

Fig.2. The expression of Cathepsin L from the soleus and plantaris muscles. Values are means \pm SE. All date are represented as the percent of control values.
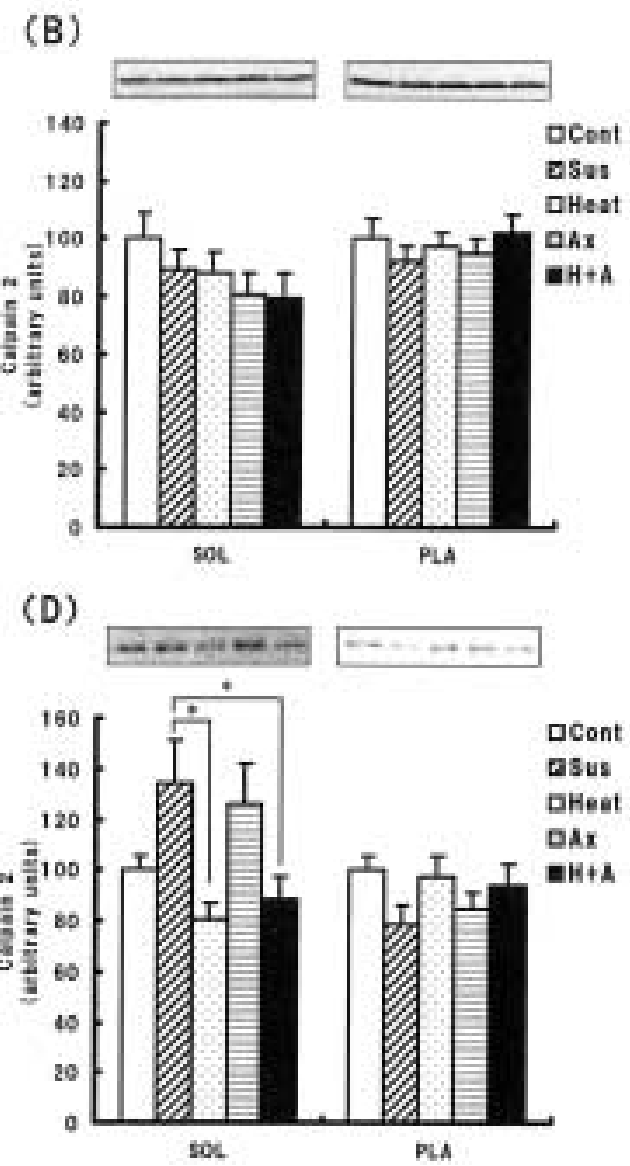

Fig.3. Effects of heat stress, astaxanthin, and combination of them on Calpain 1 and 2 in the soleus and plantaris muscles. Calpain $1(\mathrm{~A})$ and $2(\mathrm{~B})$ in the soluble fraction. Calpain 1 (C) and 2 (D) in the myofibrillar fraction. Values are means \pm $\mathrm{SE}$. All date are represented as the percent of control values. ${ }^{*} \mathrm{p}<0.05$. 
(A)
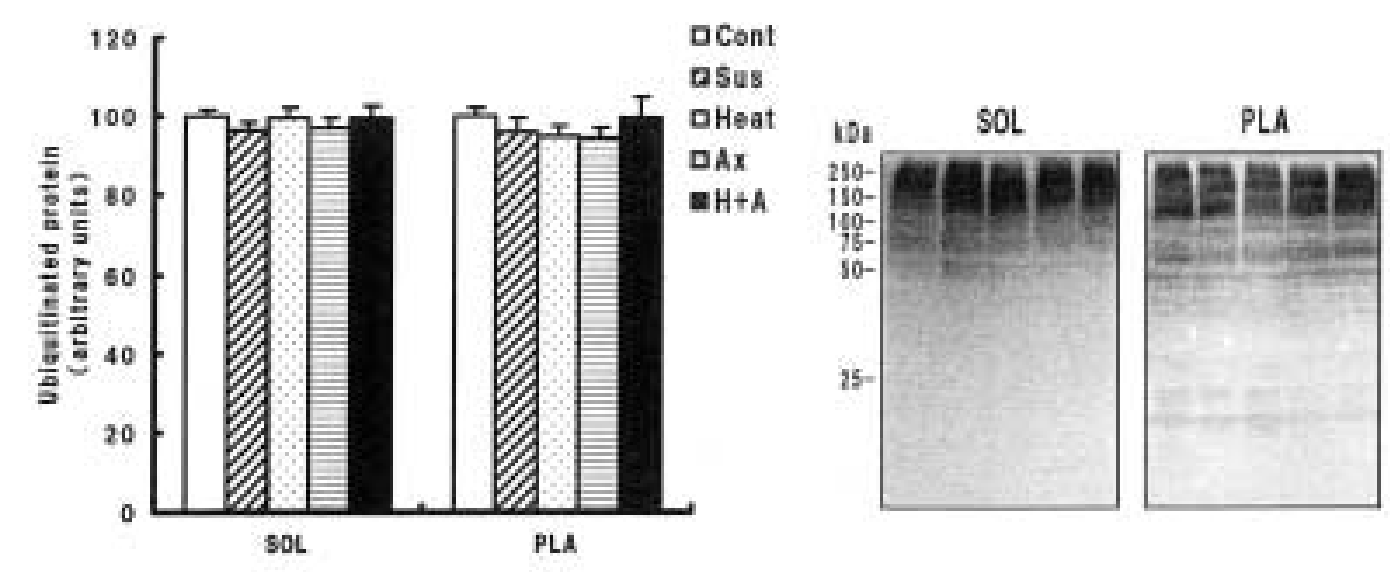

(B)
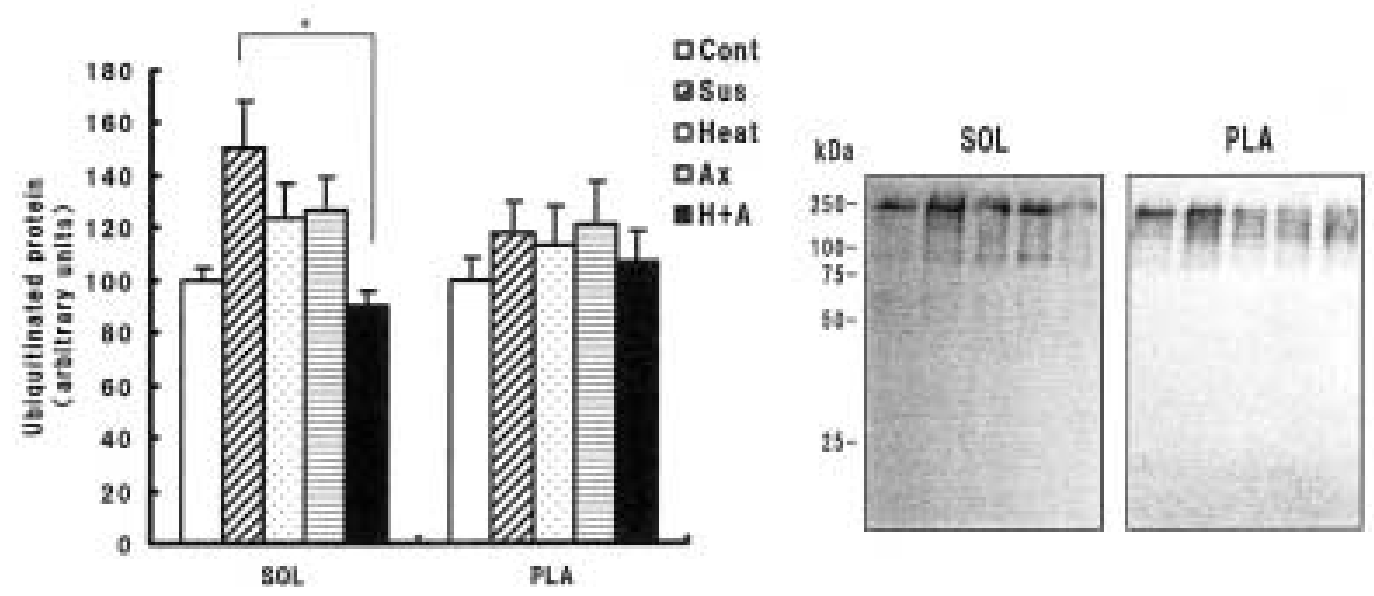

Fig.4. Effects of the combination of astaxanthin and heat stress on Ubiquitinated proteins in the soleus and plantaris muscles. Ubiquitinated proteins in the soluble (A) and myofibrillar (B) fraction. Values are means \pm SE. All date are represented as the percent of control values. ${ }^{*}<0.05$.

Caspase-3発現量に及ぼす影響を示した . Caspase -3 発現量は, 両筋のいずれの群間においても有意差は 認められなかった .

$$
\text { N. 考察 }
$$

近年 , アスタキサンチン投与や熱ストレス負荷に より，萎縮筋におけるROSの産生や酸化傷害を抑制 することで酸化ストレスの増大を軽減できることが 示されている ${ }^{8,13,14)}$. 生体内では細胞膜を構成して いるリン脂質などの不飽和脂質が, ROSの一つであ る・OHにより有害な過酸化脂質へと連鎖反応的に酸 化されるが, アスタキサンチンはこの連鎖的な過酸
化脂質の生成を抑制することで酸化ストレスの増大 を軽減することができるとされている ${ }^{15)}$. また , HSPはストレス環境から細胞を保護するために損傷 したタンパク質の凝集抑制や一部変性したタンパク 質の修復などの機能を有しているだけでなく，あら かじめ非致死的な熱ストレスを負荷することにより HSPが増大した細胞では, 兴の後に与えられる致死 的な熱ストレス，あるいは谷の他のストレスによっ て生じる傷害の程度を抑えることができるという報 告がある ${ }^{16)}$. 本研究は, このような観点から, 筋萎 縮時に熱ストレス負荷とアスタキサンチン投与の組 み合わせを処置することで, 萎縮筋における酸化ス 


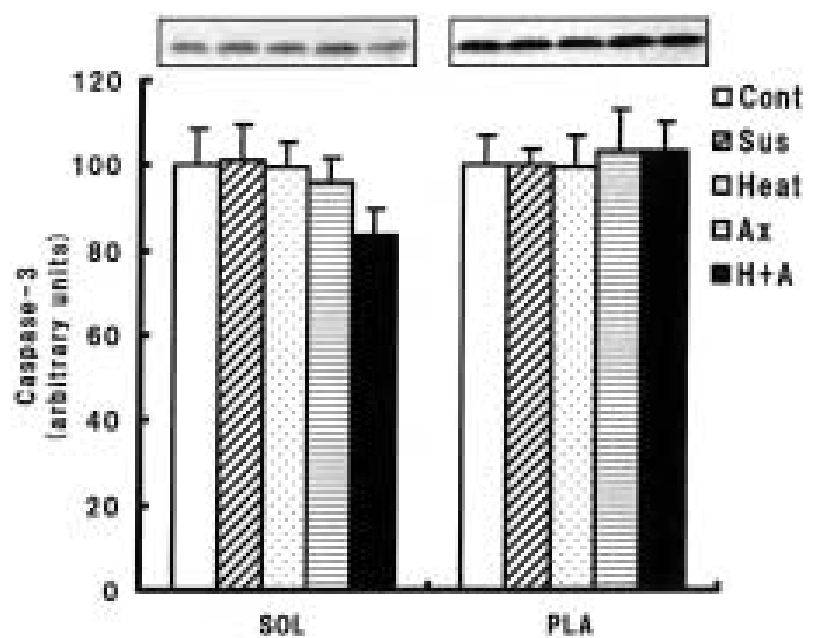

Fig.5. The expression of Caspase -3 from the soleus and plantaris muscles. Values are means \pm SE. All date are represented as the percent of control values.

トレスの増大や关れに伴うタンパク質分解を効果的 に抑制できるとの仮説を設定し，両者の組み合わせ の処置が廃用性筋萎縮に及ぼす影響について検討し た最初の研究である . 得られた所見は, 熱ストレス 負荷とアスタキサンチン投与の組み合わせの処置に よって，相対筋重量の低下を有意に抑制するには至 らなかったものの, タンパク質分解経路の指標から みた場合，抗重力筋であるヒラメ筋における筋タン パク質分解が抑制されることを示唆するものであっ た、以下に, 本研究における熱ストレス負荷とアス タキサンチン投与の組み合わせの処置と筋タンパク 質分解に関わる指標との関係について考察する .

A. 熱ストレス負荷とアスタキサンチン投与の組 み合わせの処置が酸化ストレスに及ぼす影響 尾部懸垂やギプス固定に誘発される萎縮筋では酸 化ストレスが増大することが示されており ${ }^{2)}$, これ までの研究では, 萎縮筋における酸化ストレスの増 大に伴いCu,Zn-SODの活性や発現量が元進・増加す ることが報告されている1,13,14,17) $. \mathrm{Cu}, \mathrm{Zn}$-SODは 細胞質に局在し, 細胞質内の $\mathrm{O}_{2}{ }^{-}$を消去する酵素で あり，弚の六進・増加は細胞質内における $\mathrm{O}_{2}{ }^{-}$の産 生の程度を反映している ${ }^{18)}$ 。

しかしながら, 本研究ではいずれの尾部懸垂群に おいてもCont群と比較してCu,Zn-SOD発現量に有意 な差は認められなかった . 先行研究と本研究の結果 の違いの原因は, 本研究で用いた実験プロトコルの
違いか関係しているのかもしれない . すなわち, 本 研究では尾部懸垂期間中に間欠的な熱ストレスを負 荷する際に尾部懸垂を行ったまま負荷することが困 難であつたため，実験方法論上やむを得なく接地を 行った. Miyazakiら ${ }^{19)}$ は, 不活動中に接地による機 械的な負荷を加えることで萎縮が軽減されることを 報告しており，本研究では 2 日に一度接地を行った ことによって酸化ストレスの増大が十分に生じなか った可能性がある.また, 先行研究では $6 \sim 8$ 週齢 の若齢ラットヒラメ筋は, $7 \sim 8$ 日間の不活動によ り $30 \sim 50 \%$ 萎縮がみられたのに対し 20,21$)$, 本研究 の萎縮率は $30 \%$ を下回っており, 比較的萎縮の程度 が小い結果となった .これらのことから，一時的 ではあるが尾部懸垂中の機械的な負荷か酸化ストレ スの増大を軽減したために, 酸化ストレスに対する 熱ストレスやアスタキサンチンの効果が認められな かったのかもしれない，今後は, 尾部懸垂期間中に 接地を行わないプロトコルでの検討を行い，熱スト レス負荷とアスタキサンチン投与の組み合わせの処 置か酸化ストレスに及ぼす影響を明らかにする必要 がある .

\section{B. 熱ストレス負荷およびアスタキサンチン投与} の組み合わせの処置が筋タンパク質分解経路に 及ぼす影響

生体内において酸化ストレスが増大すると, 主要 な筋タンパク質分解経路として知られるリソソーム 系, カルパイン系, ユビキチンープロテアソーム系 が活性化され，筋タンパク質の分解が六進すること が報告されている2,3) .リソソーム系, カルパイン 系が活性化される原因の一つとして, 脂質の過酸化 により細胞膜が傷害され, 細胞内カルシウム濃度が 増加することが挙げられる ${ }^{22)}$. Taillandierら ${ }^{3)}$ は, 細胞内カルシウムレベルの増加が , リソソームプロ テアーゼであるカテプシン Lやカルシウム依存性シ ステインプロテアーゼであるカルパインの活性化を 導き, リソソーム系やカルパイン系を介したタンパ ク質分解を六進させることを報告している．なお， 本研究ではカルパイン系の指標としてCalpain 1およ びCalpain 2を測定しているが, 両者では活性化に必 要なカルシウム濃度が異なり, Calpain 1が数 $\mu \mathrm{M} て ゙$ あるのに対し, Calpain 2では数mMであることが知 られている23). また, ユビキチンープロテアソーム 
系は, シグナル伝達因子や転写因子を制御している ことが明らかになっており, 筋萎縮時のタンパク質 分解において主要な役割を担っていることが示され ている ${ }^{2,3)}$. さらに, 酸化ストレスの増大は, Caspase-3を介した筋核のアポトーシスを誘導すること で筋萎縮を引き起こすことが報告されている ${ }^{2,24)}$. このように，筋萎縮時のタンパク質分解には生体内 における酸化ストレスの増大が密接に関与してお り，熱ストレス負荷とアスタキサンチン投与の組み 合わせの処置はタンパク質分解経路の亢進抑制に対 して効果的である可能性が考えられる .

本研究では, Cathepsin L発現量ならびに可用性分 画におけるCalpain 1，2発現量およびユビキチン化 タンパク質発現量は, 両筋のいずれの群間において も有意な増加は認められなかった . しかしながら , ヒラメ筋では, 筋原線維分画におけるCalpain 2発現 量は, 特別な処置を行わないSus群と比較してHeat 群およびH+A群で有意に低い值を示し, ユビキチン 化タンパク質発現量は, Sus群と比較して $\mathrm{H}+\mathrm{A}$ 群で 有意に低い値を示した .これは, 熱ストレス負荷と アスタキサンチン投与の組み合わせの処置が, HSP の誘導による細胞防御機能やストレスに対する抵抗 性の獲得 $^{16)}$, またはアスタキサンチンの細胞膜に対 する保護作用や過酸化脂質の生成反応を抑制する作 用 ${ }^{15)}$ をたらし, 細胞内カルシウムやROS産生の増 加，ならびに光れに伴う酸化ストレスの増大を抑制 することによって筋原線維分画におけるタンパク質 分解の六進を抑制したものと考えられる。また， Taillandierら ${ }^{3)}$ は，廃用性筋萎縮におけるタンパク 質分解の大部分は，活性化されたカルパインにより 細胞骨格から遊離された筋原線維タンパク質がユビ キチン化され，最終的にプロテアソームによって分 解されることで遂行されることを示唆しており，こ のことからも熱ストレス負荷とアスタキサンチン投 与の組み合わせの処置は, 特に筋原線維タンパク質 の分解抑制に対して効果的であると考えられる.

一方, 足底筋においては筋原線維分画のCalpain 1 発現量は, $\mathrm{H}+\mathrm{A}$ 群で最も低い值を示したものの, 尾 部懸垂群ではユビキチン化タンパク質に各群間で有 意な差は認められなかった .このことは , ヒラメ筋 と足底筋の萎縮の程度の違いが反映されていると考 えられる.すなわち, 速筋である足底筋は, 抗重力 筋であるヒラメ筋と比較して不活動に対する応答が
小さいため ${ }^{25)}$ ，ヒラメ筋よりも酸化ストレスによる 影響が小さいと考えられ, 足底筋におけるタンパク 質のユビキチン化の程度はヒラメ筋よりも小さいこ とが推察される．また，ユビキチンが熱ストレスや その他のストレスによって誘導され，変性タンパク 質に結合して分解シグナルとして働いていることを 考慮すると ${ }^{16)}, 7$ 日間の尾部懸垂では, 足底筋にお ける萎縮の程度は比較的小さく，ユビキチン化タン パク質発現量に有意な増加は認められなかったので はないかと考えられる .

また, 本研究では両筋のいずれの群間においても アポトーシス経路の指標であるCaspase-3発現量に 有意な差は認められなかった . Caspase-3を介した アポトーシスに起因する筋萎縮は, 尾部懸垂開始初 期に関与していることが示唆されている26). また， Caspase-3を介さずアポトーシスを誘導するアポ トーシス誘発因子やエンドヌクレアーゼGは, 弚れ

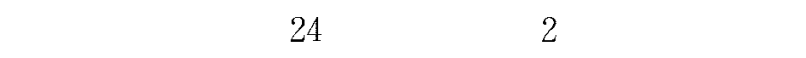
達し，兴の後低下することも報告されている ${ }^{26,27)}$. これらのことから，アポトーシスによる筋萎縮は尾 部懸垂初期に起っていたため, 本研究における尾部 懸垂開始 7 日後ではCaspase-3発現量の増加がみら れなかったと推察される.

$$
\text { V. 結論 }
$$

本研究の結果から，熱ストレス負荷とアスタキサ ンチン投与の組み合わせの処置は, 相対筋重量の低 下を抑制するには至らなかったものの, 抗重力筋で あるヒラメ筋において, 筋原線維分画のカルパイン 発現量やタンパク質のユビキチン化を抑制すること により，不活動に伴う筋タンパク質分解を抑制でき ることが示された . また, 足底筋では熱ストレス負 荷とアスタキサンチン投与, および光れらの組み合 わせを処置することにより相対筋重量の低下が軽減 されたが, 酸化ストレスや筋タンパク分解経路の指 標に変化は認められなかった .これらのことは , ヒ ラメ筋と足底筋の安静時における収縮活動水準の違 いあるいはタンパク質合成系との関連性が考えられ るが,本研究では明らかにすることはできなかった . 今後は，熱ストレス負荷およびアスタキサンチン投 与の組み合わせの処置が廃用性筋萎縮に与える影響 について, 酸化ストレスや筋タンパク質分解経路に 関わる指標の経時的な变化, 尾部懸垂期間中におけ 
る機械的負荷，さらにはタンパク質合成に関わるシ グナル伝達物質に着目して検討を行うことが必要で ある 。

\section{謝 辞}

本研究の一部は, 平成 20 年度科学研究費補助金基盤研究 (C) (杉浦, 課題番号, 20500578), 平成18年度科学研究 費補助金基盤研究 (A) (去岡, 課題番号 18200042)なら びに平成21年度山口大学教育学部研究支援経費によって実 施された .

\section{(受理日 平成22年 4 月 28 日)}

\section{U. 参 考 文 献}

1) Lawler, JM., Song, W., Demaree, SR. Hindlimb unloading increases oxidative stress and disrupts antioxidant capacity in skeletal muscle. Free Radic Biol Med, (2003), 35, 9-16.

2) Powers, SK., Kavazis, AN., McClung, JM. Oxidative stress and disuse muscle atrophy. J Appl Physiol, (2007), 102, 2389-2397.

3) Taillandier, D., Aurousseau, E., Meynial-Denis D., Bechet, D., Ferrara, M., Cottin, P., Ducastaing, A., Bigard, X., Guezennec, CY., Schmid, HP., Attaix, D. Coordinate activation of lysosomal, $\mathrm{Ca}^{2+}$-activated and ATP-ubiquitin-dependent proteinases in the unweighted rat soleus muscle. Biochem J, (1996), 316, 65-72.

4) Naito, H., Powers, SK., Demirel, HA., Sugiura, T., Dodd, SL., Aoki, J. Heat stress attenuates skeletal muscle atrophy in hindlimb-unweighted rats. J Appl Physiol, (2000), 88, 359-363.

5) Appel, HJ., Duarte, JA., Soares, JM. Supplementation of vitamin $\mathrm{E}$ may attenuate skeletal muscle immobilization atrohy. Int J Sports Med, (1997), 18, 157-160.

6) Servais, S., Letexier, D., Favier, R., Duchamp, C., Desplanches, D. Prevention of unloading induced atrophy by vitamin $E$ supplementation: Links between oxidative stress and soleus muscle proteolysis?. Free Radic Biol Med, (2007), 42, 627-635.

7) Ikemoto, M., Nikawa, T., Kano, M., Hirasaka, K., Kitano, T., Watanabe, C., Tanaka, R., Yamamoto, T., Kamada, M., Kishi, K. Cysteine supplementation prevents unweighting-induced ubiqitinqtion in association with redox regulation in rat skeletal muscle. Biol Chem, (2002), 383, 715-721.

8) 杉浦崇夫, 飯田義晴, 内藤久士, 大森大二郎, 後藤勝 正, 去岡利忠. 筋萎縮に対するアスタキサンチンの 効果 . 体力科学，(2005)，54，466.

9) Ikeda, Y., Tsuji, S., Satoh, A., Ishikura, M., Shirasawa, T., Shimizu, T. Protective effects of astaxanthin on 6-hydroxydopamine-induced apoptosis in human neuroblastoma SH-SY5Y cells. J Neurochem, (2008), 107, $1730-1740$.
10) 芝口翼, 杉浦崇夫, 古本司, 井上恒志郎, 飯田義晴, 磯山智美, 内藤久士, 大森大二郎, 去岡利忠. 長期 間のアスタキサンチン捸取がサルコペニアに及ぼす 影響。体力科学，(2008)，57，541-552。

11）鈴木信孝, 太田康之, 大野智, 井上正樹, 小池浩司, 村田幸治, 亀井 勉 . 補完代替医 7 アスタキサンチン 一サプリメント素材としての研究の現状一綜合臨牀， (2005) , 54, 2546-2551.

12) Solaro, RJ., Pang, DC., Briggs, FN. The purification of cardiac myofibrils with Triton X-100. Biochim Biophys Act (1971), 245, 259-262.

13) Selsby, JT., Dodd, SL. Heat treatment reduces oxidative stress and protects muscle mass during immobilization. Am J Physiol Regul Inter Comp Physiol, (2005), 289, R134-R139.

14) Selsby, JT., Rother, S., Tsuda, S., Pracash, O., Quindry, J., Dodd, SL. Intermittent hy perthermia enhances skeletal muscle regrowth and attenuates oxidative damage following reloading. J Appl Physiol, (2007), 102, 1702-1707.

15）眞岡孝至. カロテノイドと健康一光の多樣な生理作用 一環境と健康, 体質研究会 東京, (2007) 20,313-323.

16）内藤久士 , 小林裕幸 . 運動とタンパク質・遺伝子, 第 一版，骨格筋におけるストレスタンパク質の発現と 兴の役割 . ナップ, 東京, (2004), pp 166-180.

17) Kondo, H., Miura, M., Itokawa, Y. Oxidative stress in skeletal muscle atrophied by immobilization. Acta Physiol Scand., (1991), 142, 527-528.

18) 近藤久雄, 系川嘉則. 臨床スポーツ医学 廃用性筋萎 縮と酸化的ストレス.文光堂, (1994), 11，785-790.

19) Miyazaki, M., Noguchi, M., Takemasa, T. Intermittent reloading attenuates muscle atrophy through modulating Akt/mTOR pathway. Med Sci Sports Exerc, (2008), $40,848-855$.

20) Morita, S., Matoba, H., Sugiura, T. Effectiveness of periodic weight support activity as a countermeasure to soleus muscle atrophy during hindlimb suspension. 山口大学教育学部研究論叢, (1997), 47, 339-350.

21) Vermaelen, M., Marini, JF., Chopard, A., Benyamin, Y., Mercier, J.,Astier, C. Ubiquitin targeting of rat muscle proteins during short periods of unloading. Acta Physiol Scand, (2005), 185, 33-40.

22) Kondo, H., Itokawa, Y. Oxidative stress musclar atrophy. In., Sen, CK., Packer, L., Hanninen, O. Exercise and Oxygen Toxicity. Elsevier. Amsterdam, (1994), pp 319-342.

23) Vermaelen, M., Sirvent, P., Raynaud, F., Astier, C., Mercier, J., Lacampagne, A., Cazorla, O. Differential localization of autolyzed calpains 1 and 2 in slow and fast skeletal muscles in the early phase of atrophy. Am J Physiol Cell Physiol, (2007), 292, C1723-C1731.

24) Du, J., Wang, X., Miereles, C., Bailey, JL., Debigare, R., Zheng, B., Price, SR., Mitch, WE. Activation of caspase-3 is an initial step triggering accelerated muscle proteolysis in catabolic conditions. J Clin Invest, 
(2004), 113, 115-123.

$25)$ 大石康晴 . 筋の萎縮とトレーニング 不活動と筋萎縮 のメカニズム．体育の科学，(2005)，55，578-583.

26) Ferreira, R., Neuparth, MJ., Vitorino, R., Appell, HJ., Amado, F., Duarte JA. Evidences of apoptosis during the early phases of soleus muscle atrophy in hindlimb suspended mice. Physiol Res, (2008), 57, 601-611.
27 Dupont-Versteegden, EE., Strotman, BA., Gurley, CM. Gaddy, D., Knox, M., Fluckey, JD., Peterson, CA. Nuclear translocation of EndoG at the initiation of disuse muscle atrophy and apoptosis is specific to myonuclei. Am J Physiol Regul Integr Comp Physiol, (2006), 291, R1730-R1740. 